\title{
CHANGING IRELAND
}

\section{The Turn-around of the Turn-around in the Population of the Republic of Ireland.}

\author{
James A. Walsh \\ Department of Geography, \\ St. Patrick's College, Maynooth.
}

The provisional results of the 1991 census of population indicate a continuation of trends established in relation to fertility and migration in the early 1980 s (Cawley, 1990) which have resulted in a halting of the growth in population that commenced in the early 1960s. It is estimated that the total population declined by approximately $17,200(0.5 \%)$ since 1986 giving an estimated total of 3,523,401 for 1991. In contrast to the 1970 s, when there was widespread population growth, the geographical pattern of change for the late $1980 \mathrm{~s}$ is one of widespread decline, except in the immediate hinterlands of the largest cities. The provisional estimates issued by the Central Statistics Office (CSO) in three publications are based on summaries returned to the CSO by each of the 3,200 enumerators involved in the carrying out of the census and, as such, are subject to revision. The data contained in these preliminary reports provide estimates of the total population of each county and county borough; estimates of the total number of males and females for each of 54 urban districts, 5 county boroughs, 3 new administrative units for county Dublin and 159 rural districts as well as estimates of net migration by county for the intercensal period 1986-91; and most recently a disaggregation by age groups of the estimated number of males and females in each urban and rural district. Since the spatial and temporal changes in population numbers, distribution and composition are outcomes of the dynamic processes of fertility, mortality and migration, and the economic and social processes which influence them, this paper commences with a

Irish Geography 24(2)(1991)117-125,0075-0078/91 \$3.50

(c) Geographical Society of Ireland, Dublin. review of the components of change. This is followed by an examination of the spatial patterns of change which result from their interaction and by a consideration of the changes which have occurred in the age composition of the population, examining how these adjustments have varied across the state. Since the demographic outcome from the 1980s is different in many respects from that of the 1970s, some of the key areas of contrast will be noted throughout.

\section{Components of Change}

The total change in the population over an intercensal period is the outcome of the relationship between. natural increase (births minus deaths) and net migration. The most important influence on the level of natural increase is the birth rate. The number of births in a population is a function of two broad sets of interacting factors: those connected with demographic structure such as age composition and marriage, and those socio-economic and cultural factors which influence peoples' attitudes towards family size. Variations in marriage rates have for many years been an important influence on the birth rate for the Republic of Ireland (Walsh, 1988). Throughout the 1970s the annual number of marriages fluctuated around 21,000. Since 1980 , however, there has been a steady decline from 21,000 to just under 17,500 in 1990 . This represents a marriage rate of only 5.0 per 1000 of population which is the lowest on record since the early 1940s, and also the lowest amongst the countries of the European Community apart from France.

Quite independently of the decline in marriages 
118

there has been a very significant decline in fertility as Irish families become increasingly subject to the social and economic pressures which have already contributed to reductions in family size throughout most European countries. These includenew attitudes and behavioural norms in relation to family planning as well as an increase in the labour force participation rate for females (Blackwell, 1989). The very poor performance of the economy in the 1980s, which resulted in many families suffering from unemployment and a reduction in the levels of real disposable income for most families, may have been another influence leading parents to have smaller families. The outcome from these influences has been a decline in the total fertility rate (Walsh, 1988) from 3.23 in 1980 to 2.44 in 1986 and probably to about 2.1 in 1991 (CSO, 1988). The total number of registered births reached a peak of almost 74,400 in 1980 when the crude birth rate was 21.9 per 1000 of population. Since then there has been a steady decline at a rate of about $3.1 \%$ per annum so that the total in 1989 was only 51,659 . The corresponding birth rate was 14.7. Following a slight increase of almost $1,300,(2.5 \%)$, in 1990 the downward trend has reemerged in 1991 - the number of births registered in the first six months was almost 300 fewer than for the corresponding period in 1989. The highest birth rates over the period 1986-91 were in counties Kildare (18.3), Carlow (18.0) and Wicklow (17.5), reflecting the youthfulness of the population in these areas which has increased rapidly due to in-migration fromDublin
Changing Ireland

(Walsh, 1991(a)). While high rates were undoubtedly experienced in the expanding suburban parts of Dublin, the overall rate for the county was 15.7 which was also the rate for the state as a whole. The lowest rates were, as in previous intercensal periods, to be found in western counties such as Roscommon (13.5), Leitrim (14.1) and Kerry (14.0), areas which are characterised by more elderly populations as a result of high outmigration over many decades. Compared with the 1970 s, the greatest reductions have been in the most urbanised counties. For example, the rate for Dublin has declined from 22.1, that for Kildare from 27.3 and that for Limerick from 23.1 to15.7. By contrast the declines in the more rural parts, where rates were already low, have been much more modest e.g. from 15.7 to 13.5 for Roscommon and from 16.5 to 14.1 for Leitrim.

The average annual number of deaths over the last decade was just over 32,300 . The crude death rate has declined gradually from an annual average rate of 10.4 per 1000 of population in the 1970 s to 9.4 in the first half of the 1980 s and 9.0 for 1986-91. Significant intercounty variations are apparent, which can be related to variations in the age composition of the population.

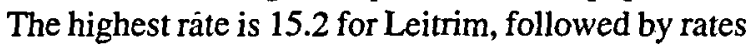
in excess of 12 for counties Mayo, Roscommon, Sligo, Cavan and Kerry. By contrast, in the more youthfully popūlated Greater Dublin region, the rates are lowest at 6.3 for Kildare, and 6.9-8.1 for Dublin, Meath and Wicklow.

Table 1: Components of population change by region $1971-1991$

\begin{tabular}{|lrrrrrr|}
\hline \multicolumn{5}{c|}{ Annual average rates per 1000 of average population } \\
Region & $1971-81$ & $1981-86$ & $1986-91$ & $1971-81$ & $1981-86$ & $1986-91$ \\
\hline East & 14.3 & 11.7 & 8.7 & 5.1 & -4.7 & -6.6 \\
Southwest & 9.6 & 8.1 & 7.0 & 2.4 & -3.7 & -8.8 \\
Southeast & 11.0 & 9.5 & 5.6 & 2.1 & -4.0 & -9.1 \\
Northeast & 10.4 & 9.2 & 5.2 & 0.3 & -4.5 & -7.2 \\
Midwest & 11.0 & 9.0 & 6.0 & 2.3 & -4.4 & -9.2 \\
Midlands & 8.6 & 8.6 & 5.3 & 1.4 & -4.0 & -11.3 \\
West & 8.1 & 7.8 & 5.1 & 2.1 & -3.1 & -6.9 \\
Northwest & 3.9 & 4.8 & 2.1 & 1.6 & -4.8 & -9.5 \\
Donegal & 8.1 & 8.3 & 5.8 & 6.3 & -1.2 & -8.4 \\
& & & & & & \\
Total & 11.3 & 9.7 & 6.8 & 3.2 & -4.1 & -7.7 \\
\hline
\end{tabular}




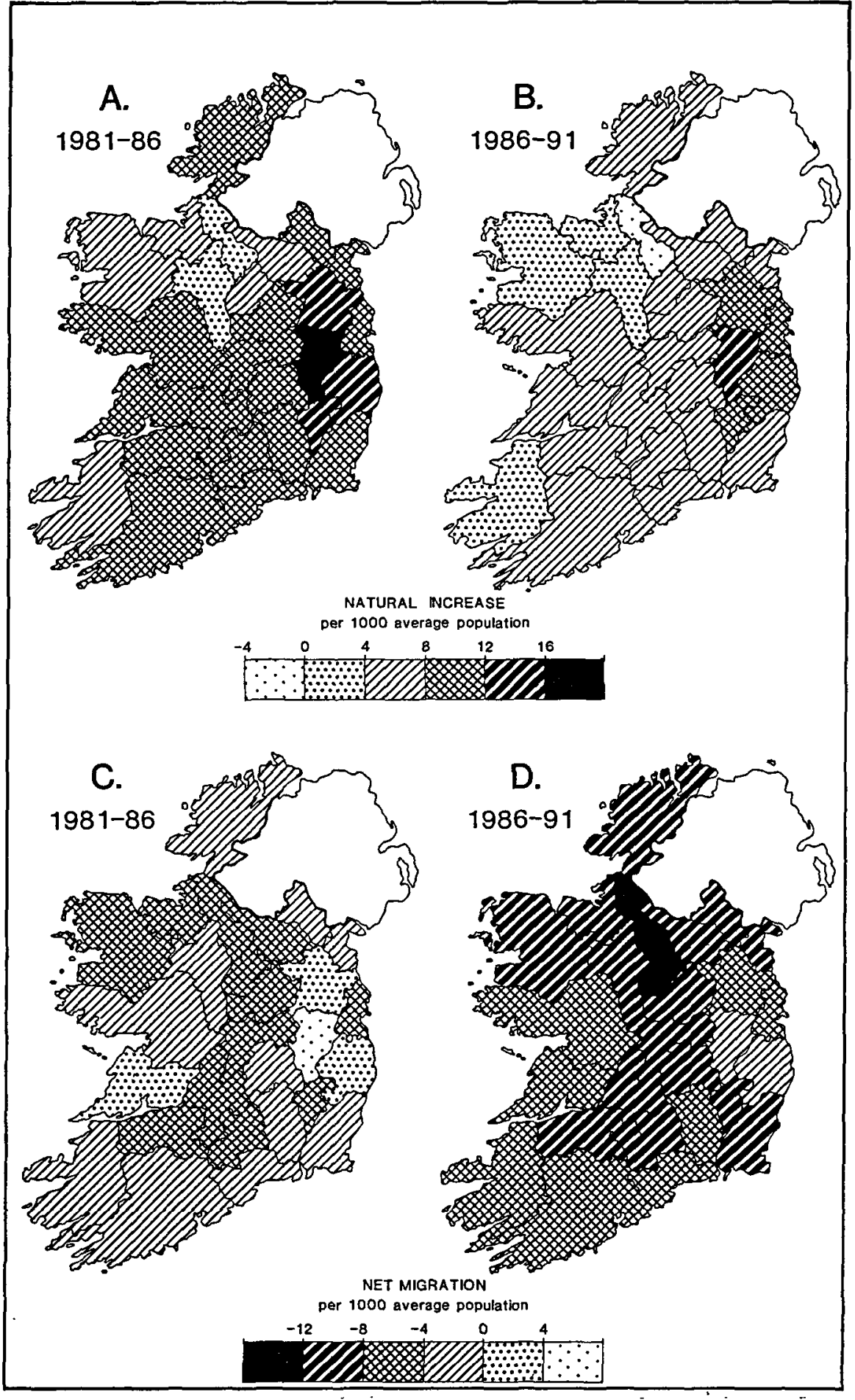

Figure 1: Natural increase and net migration rates $1981 / 86$ and 1986/91 
The joint effects of the trends in births and deaths is reflected in a decline in the rate of natural increase from 12.2 in 1980 to 5.9 per 1000 of population in 1989. The resultant change in the absolute level of natural increase was a decline from approximately 41,400 to 20,560 . In contrast to the early 1980 s when there were increases in some parts of the west and northwest, the rates for the latest intercensal period reveal considerable declines in all regions (Table 1) and counties (Figure 1). Nevertheless, significant intercounty differences remain, with the most recent rates ranging from 1.3 in Roscommon and 2.9 in Mayo to 12.0 in Kildare. Despite a considerable decline in the rates for the counties of the East region, its share of the total natural increase rose from $45.4 \%$ for $1981-86$ to $48.8 \%$ for $1986-91$. By contrast, the combined natural increase of counties Cavan, Longford, Mayo, Roscommon and Sligo (which contain $8.5 \%$ of the population) was approximately 4900 , or $4.1 \%$ of the total for the state. In county Leitrim, for the first time, the number of deaths exceeded the number of births resulting in a natural decrease of 144 persons over the inter-censal period (Walsh, 1991b).

The most widely commented upon feature of Irish demography in the 1980 s was the resumption of a high level of net emigration (Sexton, 1987; King and Shuttleworth, 1988; King, 1991; NESC, 1991). The reasons for high emigration were a combination of "push" and "pull" factors. The principal "push" factors are: a scarcity of employment opportunities for a rapidly growing labour force, considerable losses of employment in manufacturing industries due to increased competition and the effects of the international economic recession which contributed to rationalisation and increased automation, and also cutbacks in recruitment to employment throughout the public service. Against this background the number of registered unemployed persons increased from 88,000 in 1979 to over 250,000 in the summer of 1991 and the estimated level of net emigration rose from 1000 for $1981 / 82$ to 46,000 for $1988 / 89$. The "pull" factors for many are the prospects of obtaining employment in areas that would allow them to fulfill their occupational and income aspirations (Wickam, 1989; Hanlon, 1991). Hence a notable feature of recent emigration has been a high level of involvement of graduates (Sexton,1987). An additional factor in accounting for emigration from peripheral regions is an ongoing informalisation of labour markets in global cities which has created new opportunites for immigrants in secondary labour markets (Sassen, 1988) and required a revision of classical interpretations of the "push-pull" thesis (Zolberg, 1989). Corcoran (1991) has discussed the relevance of this factor in relation to recent Irish emigration to New York. The complexity of the relationships involved in recent emigration have been explored in some detail by Breathnach and Jackson (1991), NESC (1991) and Walsh (1991c).

A notable feature of the net migration in the early 1980s (which amounted to approximately 72,000 between 1981-86) was that approximately half was from Dublin, which had the highest county net outmigration rate at 7.2 per 1000 population. While some of the movement was related to residential mobility to counties Kildare, Meath and Wicklow the vast bulk was migration out of the state (Walsh,1991a). Apart from the high rate for Dublin there were also rates which were at least $50 \%$ in excess of the national figure of 4.1 for some rural counties such as Cavan, Leitrim, North Tipperary and Carlow (Figure Ic). Only four counties experienced net in-migration-Kildare $(2,761)$, Meath $(1,678)$ and Wicklow $(1,374)$ on the fringe of Dublin, and Clare which received a small net inmigration (30 persons) that can be related to the expansion of Limerick city.

In the second half of the decade there was, for the first time since the 1950s, net emigration from all counties, with the total outflow from the country estimated to be 136,500. The rate for Dublin increased only marginally from 7.2 to 7.6 so that the estimated net outflow of 38,700 from the county (some ofwhich was to other parts of the state) amounted to only $28.4 \%$ of the total net emigration. The highest rates were for some of the most rural midland and western counties, with rates in excess of 10 for Laois, Offaly, Westmeath, Longford, Leitrim, Roscommon and Mayo (Figure 1d). In addition, high rates were recorded for Limerick and Tipperary (North and South). Taking the data for the decade as a whole, it is evident that there was a shift in the balance between urban and rural areas as sources of emigrants. By the late 1980 s it is likely that there was a resumption of relatively high in-migration to Dublin from other parts of the state, particularly of graduates seeking employment in the expanding producer services sector- especially in the area of financial services. At this stage Dublin may also be benefitting from return migration of some of those who left earlier in the decade. 


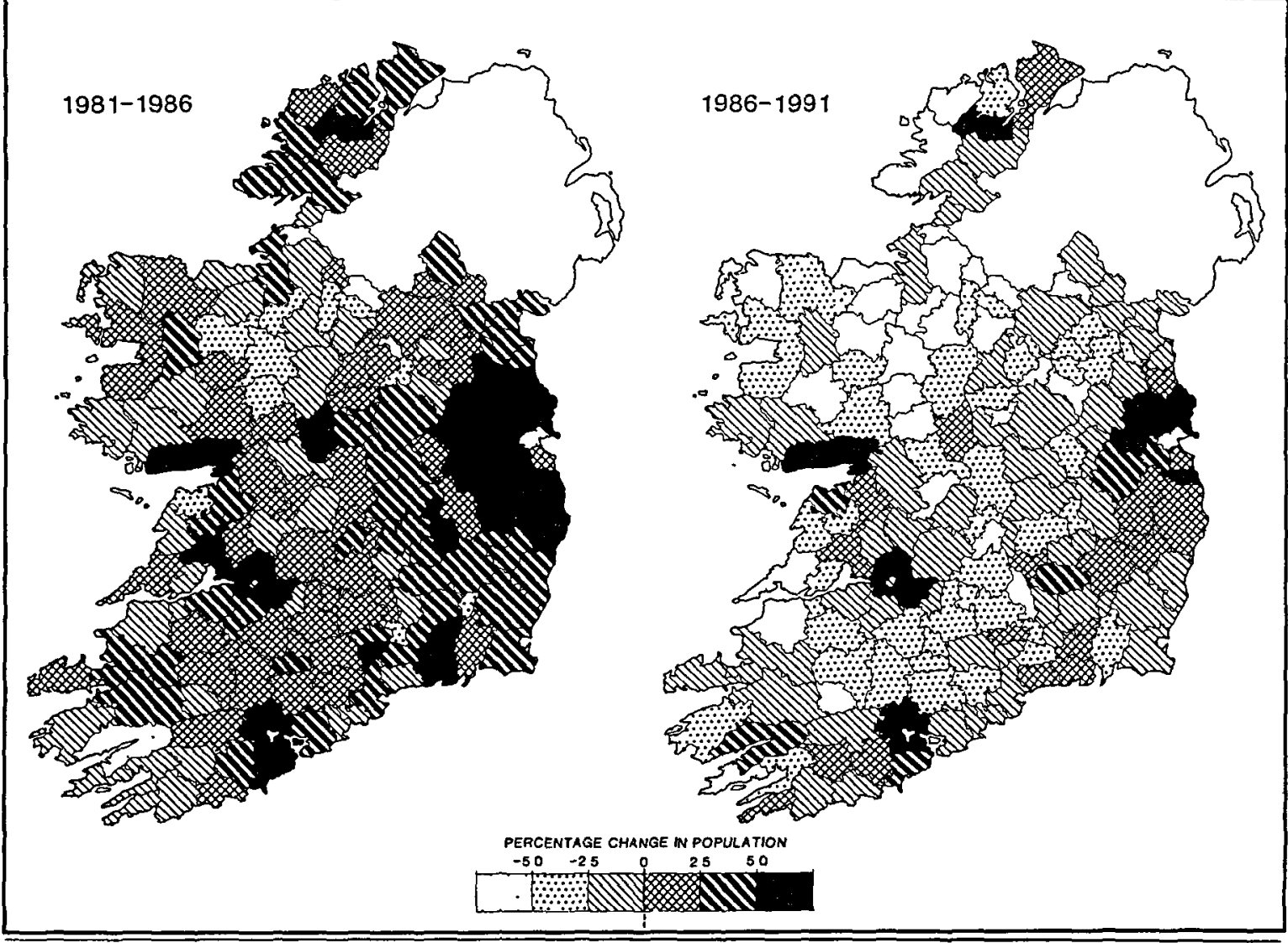

Figure 2: Percentage population change 1981-86 and 1986-91

The age cohort most affected by emigration were those aged 15-19 years. Between 1981-86 the cohort was depleted by one eighth, with the net outflow of 40,000 from this age group accounting for approximately $55 \%$ of the total net emigration over the period. Between 1986-91 the net outflow increased to almost one fifth of the cohort, amounting to approximately 62,000 persons or $46 \%$ of the total net emigration. In counties Leitrim, Roscommon and Mayo, the cohort was depleted by about $40 \%$ (Table 2). The least net losses were from the most urbanised counties, particularly those with large third level colleges which have benefitted from the inmigration of students from counties without such institutions. The very low level of net outflow from Dublin (only $4 \%$ of the cohort) is most likely due to a high inflow from other counties which largely replaced the outmigration of young Dubliners.

\section{Spatial Patterns of Change}

The overall change in population for the $1980 \mathrm{~s}$ was an increase of $2.3 \%$ or $80,000(+97,240$ between $1981 /$ 86 and -17240 between $1986 / 91$ ) which is considerably smaller than the increase of $465,200(15.6 \%)$ recorded for the 1970s under the influence of a high birth rate and a high level of net immigration. In contrast to the widespread pattern of growth in the 1970s when just over half $(51 \%)$ of the total increase occurred outside the East region, the changes in the 1980s were more concentated with three quarters of the the total increase in the East.

While the data for natural increase and net migration are only available for counties and county boroughs, it is possible to demonstrate their combined effects at the smaller level of rural districts by mapping the percentage change in the total population (Figure 2). At district 
Table 2: Estimated percentage change1986-91 in cohort aged15-19 years 1986

\begin{tabular}{|lrllll|}
\hline Carlow & -20.0 & Westmeath & -29.1 & Waterford & -20.9 \\
Dublin & -4.2 & Wexford & -25.6 & Galway & -20.0 \\
Kildare & -19.0 & Wicklow & -19.6 & Leitrim & -41.7 \\
Kilkenny & -28.3 & Clare & -30.1 & Mayo & -40.1 \\
Laois & -30.4 & Cork & -18.0 & Roscommon & -42.0 \\
Longford & -38.0 & Kerry & -31.4 & Sligo & -30.8 \\
Louth & -20.4 & Limerick & -20.1 & Cavan & -31.4 \\
Meath & -28.5 & N. Tipperary & -30.2 & Donegal & -29.1 \\
Offaly & -31.4 & S. Tipperary & -33.4 & Monaghan & -27.3 \\
\hline
\end{tabular}

level the pattern of population change in the early 1980 s was broadly similar to that of the 1970 s, with some of the highest increases on the fringes of the main urban centres, and the main areas of decline. concentrated in poor agricultural and remote parts of the northwest and extreme southwest, as well as in the Dublin county borough area. Declines occurred in 49 districts, but in only four of these was the loss greater than 5\%: the three small rural areas of Mullaghoran, Bawnboy (both in Cavan) and Kinlough in north Leitrim, and the Dublin County Borough area which experienced a decline of $7.8 \%$, amounting to 42,500 persons (Horner et al., 1987).

By the late 1980s the continuing decline in fertility and higher levels of net emigration resulted in widespread population decline. Increases were recorded in only 34 districts compared with 109 over the previous five years and 129 in the 1970s. There were only five districts with increases greater than $5 \%$, the largest being $16.3 \%$ for Celbridge No. 1 district in northeast Kildare which contains the rapidly expanding towns of Leixlip, Maynooth and Celbridge. Apart from the growth around Dublin the remaining districts for which increases were recorded are located mostly around the other cities. There are only a couple of rural areas which appear to have had an increase in population Kenmare in the southwest where increases have been recorded for all adult age groups, and Inishowen in north Donegal where there have been a number of successful initiatives in relation to local development (O'Cinneide, 1991). Throughout most of the rural areas the pattern of decline was more extensive and more intense with 30 districts experiencing declines in excess of 5\%. However, in the Dublin County Borough area there was a reduction in the level of population decline from just over 42,000 to about 25,000 , which may be partly attributed to an increase in the number of young professional people who are willing to purchase town houses or small apartments in select areas of the inner city. In contrast to the Dublin experience there has not been any reduction in the scale of population decline in either Cork or Limerick County Boroughs.

\section{Population Structure}

Apart from the changes observed in relation to the size and distribution of the population, the 1991 census also reveals a reversal of the imbalance between males and females in the total population. Throughout the period 1961-1981 the number of females per 1000 males in the population had remained virtually unchanged at 990 . By 1986 the number of females marginally outnumbered males, and by 1991 the ratio had increased to 1,011 . The reasons for the increase between 1981 and 1991 of almost 57,000 females as compared to 23,000 males are firstly, a greater natural increase among females (approximately 8,700 more) and secondly, a much higher level of male emigration, the net outflow for males being estimated at almost 116,800 - over 25,000 more than that for females. The improvement of the gender ratio was most marked in the cohort aged 15-34 years in 1981 for which the ratio increased from 965 to 1,009 . The higher net emigration rates from predominantly rural areas has resulted in the increases in the gender ratios for these areas being greater than those for Dublin. For example, the ratio for the total population in Mayo increased from 961 to 978 compared with an increase from 1,075 to 1,082 for Dublin County and County Borough. 
Table 3: Population Change by Age Groups 1971 - 1991

\begin{tabular}{|lrrrrrr|}
\hline & \multicolumn{3}{c}{ Absolute change (000s) } & \multicolumn{3}{c|}{ Percentage change } \\
Age group & $1971-81$ & $1981-86$ & $1986-91$ & $1971-81$ & $1981-86$ & $1.86-91$ \\
\hline $0-14$ yrs & $+112,600$ & $-19,000$ & $-80,800$ & +12.1 & -1.8 & -7.9 \\
$15-24$ & $+119,600$ & $+15,000$ & $-14,200$ & +24.8 & +2.5 & -2.3 \\
$25-44$ & $+211,600$ & $+84,900$ & $+31,700$ & +33.8 & +10.1 & +3.4 \\
$45-64$ & $-17,700$ & $+1,000$ & $+28,000$ & -2.9 & +0.2 & +4.7 \\
$65+$ & $+39,100$ & $+15,400$ & $+18,000$ & +11.9 & +4.2 & +5.1 \\
& & & & & & +15.6 \\
Total & $+465,200$ & $+97,200$ & $-17,200$ & +2.8 & -0.5 \\
\hline
\end{tabular}

The preliminary estimates of the age composition of the population show that there were 95,000 fewer people aged under 25 years, and 46,000 aged over 45 as compared with 1986 . The corresponding changes over the previous five years were $-4,000$ and $+16,400$ respectively. Consequently the proportion of the population aged under 25 years declined from almost $48 \%$ in 1981 to $44 \%$ in 1991 . The scale of the contrasts between the1970s and the 1980s are summarised in Table 3. Half of the total increase in the 1970s was among those aged under 25 years in 1981 which gave rise to "The Young Europeans" slogan in programmes to market Ireland as a place for investment. By contrast, in the 1980s over three quarters of the net increase in the population was among those aged over 45 years in 1991 , compared with only $4.6 \%$ for the same age groups in the 1970s. The ageing of the Irish population which has been accelerated by age selective emigration is in keeping with trends already established in most European countries (Council of Europe,1989). The variability between regions in the changing age composition of the population is summarised in Table 4. By far the highest level of decline in the young population took place in Dublin County and County Borough which also had a very high increase in its elderly population. The increase of almost one quarter in the population aged $25-44$ years in the counties surrounding Dublin reflects the high level of inmigration to these counties of young couples and families seeking cheaper homes that are within commuting distance of Dublin. In the Northwest there has been a decline in all except the 25-44 age groups. In this region almost one sixth of the population are already aged over 65 years compared with $8.6 \%$ in the counties around Dublin.

\section{Conclusions}

The combined effects of a significant decline in fertility to levels which are closer to the norm in most European countries, coupled with a resumption of high levels of net emigration, have led to a halting of the increase in population observed at each census since 1961. By the late 1980 s, the effects of these demographic adjustments were evident throughout most parts of the state, with limited increases confined mainly to the hinterlands of the major cities. The share of the total population residing in the East region has continued to increase, which has implications for regional and local planning (Walsh, 1991d). The rapid decline in fertility has already had serious effects on the structure of the population and on the demand for certain occupations, most notably primary and second level teachers. By contrast the third level sector is being stretched to cope with the growing numbers of students'seeking places in colleges and universities. In rural areas the effects of low levels of natural increase and high out-migration have implications for the provision of services such as public transport, postal delivery, police and medical services, as well as basic shopping facilities. The social importance of these services is evident from the protests which emerged against the proposals of An Post to close some of their small rural post offices. The prospects for the immediate future are not very encouraging. The number of new entrants to the labour force is expected to remain high 
Table 4: Absolute and percentage changes 1981 - 1991 in the number of persons in selected age groups, by region.

\begin{tabular}{|lrrrrrr|}
\hline Region / Age group & $0-14$ & $15-24$ & $25-44$ & $45-64$ & $65+$ & Total \\
\hline Dublin & $-40,700$ & $-4,000$ & $+35,600$ & $+17,700$ & $+12,700$ & $+21,300$ \\
& -13.9 & -2.0 & +13.7 & +10.8 & +14.7 & +2.1 \\
Remainder of East & -200 & $+6,800$ & $+17,700$ & $+9,600$ & $+4,700$ & $+38,400$ \\
& -0.2 & +14.5 & +23.0 & +22.6 & +19.8 & +13.4 \\
Southeast & $-10,900$ & -500 & $+13,100$ & $+2,800$ & $+3,900$ & $+8,400$ \\
& -9.2 & -0.8 & +14.8 & +4.8 & +9.6 & +2.2 \\
Southwest & $-16,500$ & +500 & $+16,300$ & $+2,700$ & $+3,700$ & $+6,300$ \\
& -10.6 & +0.5 & +13.0 & +2.5 & +6.0 & +1.2 \\
Northeast & $-4,400$ & $-1,100$ & $+5,400$ & -800 & $+2,100$ & $+1,200$ \\
& -7.4 & -3.4 & +11.9 & -2.4 & +9.8 & +0.6 \\
Midwest & $-10,300$ & +500 & $+8,200$ & $+1,600$ & $+2,300$ & $+2,300$ \\
& -10.9 & +1.0 & +11.1 & +2.9 & +6.9 & +0.7 \\
Midlands & $-7,200$ & $-2,500$ & $+7,400$ & $-2,400$ & $+2,600$ & $-1,900$ \\
& -9.1 & -6.0 & +12.9 & -5.1 & +8.6 & -0.7 \\
West & $-5,400$ & +500 & $+8,500$ & -700 & $+1,300$ & $+4,200$ \\
Northwest & -6.4 & +1.2 & +13.1 & -1.4 & +3.3 & +1.5 \\
Donegal & $-2,000$ & $-1,200$ & $+1,700$ & $-1,600$ & -100 & $-3,100$ \\
& -8.6 & -9.1 & +9.3 & -9.6 & -0.6 & -3.7 \\
& $-2,500$ & $+1,700$ & $+3,000$ & +400 & +100 & $+2,900$ \\
& -6.3 & +9.2 & +10.7 & +2.1 & +0.4 & +2.3 \\
\hline Republic of Ireland & $-99,800$ & +800 & $+116,600$ & $+29,000$ & $+33,400$ & $+80,000$ \\
& -9.6 & +0.1 & +13.9 & +4.9 & +9.1 & +2.3 \\
\hline
\end{tabular}

Note: discrepancies in row and column totals are due to rounding of absolute numbers to nearest hundred.

Percentages (in italics) have been calculated from actual estimates of changes.

throughout most of the remainder of this decade (CSO, 1988). In the twelve months up to April 1991 there was a sharp reduction in emigration which resulted in a substantial increase in unemployment. This reduction in emigration was mostly due to the slowdown in the UKeconomy. Mosteconomic commentators are agreed that the prospects for job creation are unlikely to be able to meet the expected demand in the medium term. High levels of emigration will therefore probably be a major feature of the 1990 s - so long as there are suitable destinations to migrate to. The long term task of generating a sufficient number of satisfactory employment opportunites for a highly educated labour force will require a fundamental reappraisal of the strategies relied upon to create and redistribute wealth.
One of the outstanding contradictions of the last decade was the very favourable performance of Ireland as an economic space in which to create profits while at the same time many of its citizens found it to be an unsatisfactory place in which to seek employment at a level commensurate with their aspirations. More detailed analysis of the trends identified here and their underlying causes must await the publication of disaggregated final results of the Census.

\section{Acknowledgement}

Special thanks are due Jim Keenan for producing the maps. 


\section{References}

BLACKWELL, J. (1989) Women in the Labour Force. Employment Equality Agency, Dublin.

BREATHNACH, P. and JACKSON, J. (1991) Ireland, emigration and the new international division of labour, in, King, R. (ed.) Geographical Perspectives on ContemporaryIrish Migration. Geographical Society of Ireland, Special Publication No. 6, Dublin, 1-10.

CAWLEY,M. (1990) Population change in the Republic of Ireland 1981- 1986, Area 22, 1,67-74.

COUNCIL of EUROPE (1989) Recent demographic developments in the member states of the Council of Europe. Strasbourg.

CORCORAN, M.P. (1991) Informalization of metropolitan labour forces: the case of Irish immigrants in the New York construction industry, Irish Journal of Sociology 1, 31-51.

CSO (1982) Census of Population of Ireland 1981, Volume 1, Areas. Stationery Office, Dublin.

CSO (1987) Census 86, Volume 1, Population Classified by Area. Stationery Office, Dublin.

CSO (1988)Population and Labour Force Projections 1991 2021. Stationery Office, Dublin.

CSO (1991a) Census of Population of Ireland 1991; Pre- liminary Population Figures. Stationery Office, Dublin.

CSO (1991b) Census of Population of Ireland 1991: Preliminary Report, Areas. Stationery Office, Dublin.

CSO (1991c) Census of Population of Ireland 1991: Preliminary Report, Age Groups. Stationery Office, Dublin.

HANLON, G. (1991) The emigration of Irish accountants: economic restructuring and producer services in the periphery, Irish Journal of Sociology 1, 52-65.

HORNER, A. A. and DAULTREY, S. G. (1980) Recent population changes in the Republic of Ireland, Area 12, 129-35.

HORNER, A. A., WALSH, J. A. and HARRINGTON, V.P. (1987) Population in Ireland: a census atlas. Department of Geography, University College, Dublin.

KING, R. and SHUTTLEWORTH, 1. (1988) Ireland's new wave of emigration in the 1980s, Irish Geography 21(2), 104-8.

KING, R. (ed.) (1991) Geographical Perspectives on Con- temporary Irish Migration. Geographical Society of Ireland, Special Publication No.6, Dublin.

NESC (1991) The Economic and Social Implications of Emigration, Report No.90. Stationery Office, Dublin.

O'CINNEIDE, M. (1991) An innovative approach to local economic development in Inishowen, Republic of Ireland. Paper presented to XI International Seminaron Marginal Regions, Lillehammer, Norway.

SASSEN, S. (1988) The Mobility of Labour and Capital: $a$ study in international investment and labor flow. Cambridge University Press, New York.

SEXTON, J. J. (1987) Recent changes in the Irish population and in the pattern of emigration, Irish Banking Review, Autumn, 31-44.

WALSH, J. A. (1988) Components of demographic change in the Republic of Ireland, Geographical Viewpoint 16, 45-59.

WALSH, J. A. (1991a) Inter-regional migration in the Republic of Ireland: patterns and processes, in, King, R. (ed.) Geographical Perspectives on Contemporary Irish Migration. Geographical Society of Ireland, Special Publication No. 6, Dublin, 96-110.

WALSH, J. A. (1991b) Population change in the Republic of Ireland in the 1980s, Geographical Viewpoint 19, 89 98.

WALSH, J. A. (1991c) Demographic and labour force adjustments in the context of economic restructuring: the experience of Ireland in the 1980s. Paper presented to XI International Seminar on Marginal Regions, Lillehammer, Norway.

WALSH, J. A. (1991d) Regional and local development in Ireland in the 1990s, in, Walsh, J. A. (ed.) Local Eco: nomic Development and Administrative Reform. Regional Studies Association (Irish Branch), Dublin, 1024.

WICKHAM, J. (1989) The over-educated engineer? The work, education and careers of Irish electronic engineers, IBAR - Journal of Irish Business and Administrative Research. 10, 19-33.

ZOLBERG, A. (1989) The next waves: migration theory for a changing world, International Migration Review, 23, 403-29. 